Original Research Paper

\title{
Study on the Suitable Irrigation Amount of Microporous Membrane Water-Fertilizer Integration of Tomato in Spring in Plastic Greenhouse
}

\author{
Xiao Huaijuan, Du Qingjie, Zhang Jiaxin, Li Juanqi and Wang Jiqing* \\ College of Horticulture, Henan Agricultural University, Zhengzhou 450002, China
}

\author{
Article history \\ Received: 07-05-2020 \\ Revised: 28-05-2020 \\ Accepted: 11-06-2020 \\ Corresponding Author: \\ Wang Jiqing \\ College of Horticulture, Henan \\ Agricultural University, \\ Zhengzhou 450002, China \\ Email:wangsongly02@163.com
}

\begin{abstract}
Water-saving irrigation is an important measure to alleviate the shortage of water resources in China. In this study, the growth, nutrient distribution, quality and yield of Tomato under different irrigation treatments are studied by using microporous membrane water-fertilizer integrated technology and the optimal irrigation water quantity under the condition of microporous membrane water-fertilizer integration was determined. The results show that the stem diameter and the fresh and dry weight of tomato increased under the treatment of microporous membrane irrigation, among which the irrigation of $84 \mathrm{~m}^{3} \cdot 667 \mathrm{~m}^{-2}$ was the best, comparing with the traditional flooding irrigation. Microporous membrane irrigation promotes the accumulation of $\mathrm{N}, \mathrm{P}$ and $\mathrm{K}$ in tomato plants. The organic acid content of tomato fruit was the highest under the treatment of $108 \mathrm{~m}^{3} .667 \mathrm{~m}^{-2}$ and the lycopene content is the highest under the treatment of $96 \mathrm{~m}^{3} \cdot 667 \mathrm{~m}^{-2}$. However, soluble protein, soluble solids, $\mathrm{VC}$ content and sugar acid ratio are the highest under the treatment of $84 \mathrm{~m}^{3} .667 \mathrm{~m}^{-2}$ and the yield and water use efficiency of tomato are the highest under this treatment. Generally, the optimal irrigation amount of tomato under the condition of microporous membrane water-fertilizer integration is $84 \mathrm{~m}^{3} \cdot 667 \mathrm{~m}^{-2}$. The experiment clarifies the crop water demand characteristics and provides a certain theoretical basis for the application of water-saving irrigation technology and high-yield cultivation.
\end{abstract}

Keywords: Tomato, Irrigation Amount, Microporous Membrane, Growth, Yield

\section{Introduction}

According to the statistics of the National Bureau of statistics (NBS, 2018), the total water consumption of China in 2017 was 604 million $\mathrm{m}^{3}$, of which the agricultural water consumption accounted for $62 \%$. In China, although the total amount of agricultural water has achieved zero growth for many years, the shortage of water resources has not been improved. Therefore, it is of great significance to develop efficient and watersaving agriculture and reduce the total amount of agricultural water consumption to alleviate the problem of water shortage. In traditional agriculture, farmers often adopt the way of flood irrigation. On the one hand, the irrigation water seeps down a lot, on the other hand, it evaporates a lot and the crop can use less water, which causes serious water waste (Al-Ghobari and Dewidar, 2018). In recent years, with the development of irrigation technology, drip irrigation, infiltration irrigation and other water-saving irrigation facilities are widely used in the process of irrigation (Ayars et al., 1999; Wang et al., 2020a). The results showed that drip irrigation and infiltration irrigation could save more than $50 \%$ water, yield improvement and increase water use efficiency by 2-5 times (Hanson and May, 2006; Karlberg and Vries, 2004; Song et al., 2009). New water-saving irrigation technologies, such as drip irrigation and infiltration irrigation, have good water-saving and production increasing effects, but they need to install supporting pressure equipment, water pipeline and emitter, which increased the cost and need high water quality requirements (Li et al., 2019; Mostafa et al., 2018; 
Singh et al., 2019) and ultimately limit the application of water-saving irrigation technology in agricultural production. The perforated membrane is used to replace the pipes, such as drip irrigation belt and drip irrigation pipe and the perforated membrane is laid in the ridged ditch and then a layer of plastic film is covered on it (Wang et al., 2020b). The water flows between the plastic film and the perforated membrane and penetrates into the soil through the small holes on the film so as to carry out non pressure self-flow irrigation. The microporous membrane water-fertilizer integrated technology can not only reduce the cost of irrigation equipment, but also solve the problem of blocking. However, the research on non-pressure gravity irrigation by water-fertilizer integration using microporous membranes is rarely explored and it is not clear how much water can be used to meet the needs of crop growth and development.

Therefore, this study using microporous membrane water-fertilizer integrated technology and comparing with traditional furrow irrigation, seted different irrigation amount treatment. The effects of different irrigation amount on tomato growth, nutrient distribution, quality and yield were studied under the condition of microporous membrane water-fertilizer integration, in order to determine the optimal irrigation water quantity and the characteristics of crop water demand and provide a theoretical basis for the application of water-saving irrigation technology and high-yield cultivation.

\section{Materials and Methods}

\section{Experiment Materials}

Water soluble fertilizer (18-7-20) is produced by Yichuan Fufeng plant nutrient Industry Co., Ltd. Tomato variety is ' $\mathrm{k} 1601$ ', the seedlings were transplanted at 60 days of age. The base fertilizer is three element compound fertilizer (15-15-15). The perforated plastic film is made of 8 -wire agricultural film, with a width of $60 \mathrm{~cm}$, a length of $40 \mathrm{~cm}$ longer than the ridge, a diameter of $3 \mathrm{~mm}$, a spacing of $20 \mathrm{~cm}$, a width of 12.5 $\mathrm{cm}$ and 3 holes in parallel in each row.

\section{Time and Place of Experiment}

The field experiment was conducted in the plastic shed of Zhengzhou international fine variety science and Technology Exhibition Park (34 $16^{\prime}$ and $34^{\circ} 39^{\prime} \mathrm{N}$, $113^{\circ} 30^{\prime}$ and $113^{\circ} 54^{\prime} \mathrm{E}$ ), Xinzheng, from March 16 to July 12, 2017.Before planting, the basal fertilizer is 1000 $\mathrm{kg} \cdot 667 \mathrm{~m}^{-2}$ of dried chicken manure and $35 \mathrm{~kg} \cdot 667 \mathrm{~m}^{-2}$ of three element compound fertilizer. The planting depth was no more than $1 \mathrm{~cm}$ of the original substrate surface, $80 \mathrm{~cm}$ in the large row, $50 \mathrm{~cm}$ in the small row and $46.6 \mathrm{~cm}$ in the distance between the plants. The plant spacing is $46.6 \mathrm{~cm}$ and 2200 seedlings were planted in each $667 \mathrm{~m}^{2}$. After planting, the large and small rows were watered thoroughly with the amount of water of $60 \mathrm{~m}^{3} \cdot 667 \mathrm{~m}^{-2}$. In addition to Control (CK), all the other treatments were laid with perforated film and covered with film on the ridge. The treatment was taken 3 weeks later.

\section{Experiment Design}

In this experiment, 4 irrigation treatments were designed, including, A: $120 \mathrm{~m}^{3} \cdot 667 \mathrm{~m}^{-2}$, B: $108 \mathrm{~m}^{3} \cdot 667$ $\mathrm{m}^{-2}$, C: $96 \mathrm{~m}^{3} \cdot 667 \mathrm{~m}^{-2}$ and D: $84 \mathrm{~m}^{3} \cdot 667 \mathrm{~m}^{-2}$. The amount of topdressing (18-7-20) was $70 \mathrm{~kg} \cdot 667 \mathrm{~m}^{-2}$ and local traditional irrigation $124 \mathrm{~m}^{3} \cdot 667 \mathrm{~m}^{-2}$ and fertilization $125 \mathrm{~kg} \cdot 667 \mathrm{~m}^{-2}$ was as a CK. The specific irrigation and fertilization system was carried out according to Table 1 and stopped the treatment of fertilizer and water 2 weeks before harvest. Each treatment was set with 3 repetitions and random block arrangement. The experiment area was $6 \mathrm{~m}$ long and $1.3 \mathrm{~m}$ wide and the edge of the area was provided with a protection row. 7 Plants were randomly sampled for each treatment to collect the relevant data. Plant height, stem diameter and leaf number were measured once every 20 days before planting (before topping) and the third ear fruit taken for fruit determination.

\section{Measurement Items and Methods}

\section{Growth Index}

The height from stem base to plant growth point was measured by tape. The stem diameter (from the base of stem to the middle of cotyledon) was measured by digital vernier caliper. The number of leaves longer than $5 \mathrm{~cm}$ was counted. The dry and fresh weight of the above ground and underground parts were measured by analytical balance, the fresh weight was directly measured by balance, dry weight: Green removing at $105^{\circ} \mathrm{C}$ for $15 \mathrm{~min}$ and bake at $85^{\circ} \mathrm{C}$ at constant temperature to constant weight before weighing.

\section{Determination of NPK Content}

0-20 cm, 20-40 cm and 40-60 $\mathrm{cm}$ of basicsoil samples were taken before treatment and the roots, stems and leaves of dried plant and 0-20 cm, 20-40 cm, 40-60 $\mathrm{cm}$ of soil samples were taken after treatment. According to the method of Bremner (1960). The sample was prepared and the Nitrogen $(\mathrm{N})$ content was determined by Kjeldahl method. The content of Phosphorus (P) was determined by vanadium molybdate colorimetry and the content of potassium (K) were determined by flame photometric method (Burcea et al., 2016). 


\section{Quality, Yield and Water Use Efficiency}

Anthrone colorimetry was used to determine the content of soluble sugar, soluble sugar $\left(\mathrm{ug} \cdot \mathrm{g}^{-1}\right)=$ A*N/W (A: The soluble sugar obtained in the standard curve (ug), N: The dilution ratio, W: The sample weight $(\mathrm{g})$ ). The content of soluble protein was measured by coomassie blue staining, soluble protein content $\left(\mathrm{mg} \cdot \mathrm{g}^{-1}\right)=(\mathrm{C} * \mathrm{~V} 2) /(1000 * \mathrm{~V} 1 * \mathrm{~W})(\mathrm{C}$ : The value of standard curve(ug), V2: The volume of extract $(\mathrm{ml}) ; \mathrm{V} 1$ is the amount of sample added during determination $(\mathrm{mL}), \mathrm{W}$ : The fresh weight of the sample(g)). The content of vitamin $\mathrm{C}$ was determined by molybdenum blue colorimetry, Vitamin $\mathrm{C}$ content $\left.\left(\mathrm{mg} \cdot 100 \mathrm{~g}^{-1}\right)=\left\{\left(\mathrm{V}_{\mathrm{A}}-\mathrm{V}_{\mathrm{B}}\right) * \mathrm{C} * \mathrm{~T}\right\} /(\mathrm{D} * \mathrm{~W})\right\} * 100\left(\mathrm{~V}_{\mathrm{A}}\right.$ : The average milliliter of fuel for titration sample $(\mathrm{mL})$, $\mathrm{V}_{\mathrm{B}}$ : The average milliliter number of dyes for titration of blank control $(\mathrm{mL}), \mathrm{C}$ : The total $\mathrm{ml}$ of sample extract $(\mathrm{ml}), \mathrm{D}$ : The milliliter number of sample extract obtained during titration $(\mathrm{mL}), \mathrm{T}$ : The milligram of ascorbic acid that can be oxidized by 1 $\mathrm{mL}$ dye $(\mathrm{mg}), \mathrm{W}$ : The weight of the sample to be tested(g)). The content of lycopene is determined by colorimetry, the percentage content of lycopene $=$ $\{\mathrm{C} * \mathrm{~V} 3 *(\mathrm{~V} 1 / \mathrm{V} 2) *(1 / \mathrm{W})\} * 100 \%(\mathrm{C}$ : The concentration of lycopene from the standard curve $(\mathrm{mg} / \mathrm{L}), \mathrm{V} 1$ : The volume of the extract $(\mathrm{mL}), \mathrm{V} 2$ : The volume of the extracted solution $(\mathrm{mL})$; V3: The volume of the solution to be measured (1), W: The weight of the sample (mg)). The soluble solids were measured by sugar meter and organic acids were determined by acid-base titration. Sugar acid ratio $=$ soluble sugar/titratable acid. Specific methods referred to the method of Li et al. (2000).

The yield of tomato fruits was calculated by plot; water use efficiency WUE $=\mathrm{Y} / \mathrm{I}(\mathrm{Y}$ : The total yield $\mathrm{kg} \cdot 667 \mathrm{~m}^{-2}$ of each treatment, I: The irrigation amount $\mathrm{m}^{3} \cdot 667 \mathrm{~m}^{-2}$ in the growth period).

\section{Data Analysis}

DPS 7.05 software was used to analyze the variance of all experimental data and LSD test was used to compare the differences among the treatments $(\mathrm{P}<0.05)$.

Table 1: The plan for watering and fertilization after tomato planting

\begin{tabular}{|c|c|c|c|c|c|c|c|c|c|c|c|}
\hline \multicolumn{2}{|c|}{ Weeks after planting } & 3 & 6 & 7 & 8 & 9 & 10 & 11 & 12 & 13 & 14 \\
\hline \multirow[t]{6}{*}{ A } & Weeks\#day & $3 \# 3$ & $6 \# 4$ & - & $8 \# 4$ & 9\#6 & $10 \# 6$ & $11 \# 4$ & $12 \# 1$ & $13 \# 4$ & $14 \# 1$ \\
\hline & & & & & & & & & $12 \# 6$ & & $14 \# 6$ \\
\hline & Irrigation amount & 6 & 12 & - & 12 & 12 & 12 & 12 & 12 & 12 & 12 \\
\hline & $\left(\right.$ ton $\cdot$ time $^{-1} \cdot 667 \mathrm{~m}^{-2}$ ) & & & & & & & & & 12 & 6 \\
\hline & Topdressing amount & - & 4 & - & 10 & 10 & 8 & 8 & 6 & 6 & 6 \\
\hline & $\left(\mathrm{kg} \cdot \mathrm{time}^{-1} \cdot 667 \mathrm{~m}^{-2}\right)$ & & & & & & & & 6 & & 6 \\
\hline \multirow[t]{6}{*}{ B } & Weeks\#day & $3 \# 3$ & - & $7 \# 7$ & $8 \# 6$ & 9\#7 & - & $11 \# 1$ & $12 \# 6$ & $13 \# 4$ & $14 \# 2$ \\
\hline & & & & & & & $11 \# 7$ & & & $14 \# 7$ & \\
\hline & Irrigation amount & 6 & - & 12 & 12 & 12 & - & 12 & 12 & 12 & 12 \\
\hline & $\left(\right.$ ton $\cdot$ time $\left.^{-1} \cdot 667 \mathrm{~m}^{-2}\right)$ & & & & & & & 12 & & & 6 \\
\hline & Topdressing amount & - & - & 6 & 10 & 10 & - & 8 & 8 & 8 & 8 \\
\hline & $\left(\mathrm{kg} \cdot \mathrm{time}^{-1} \cdot 667 \mathrm{~m}^{-2}\right)$ & & & & & & & 8 & & & 4 \\
\hline \multirow[t]{6}{*}{$\mathrm{C}$} & Weeks\#day & $3 \# 3$ & - & $7 \# 1$ & $8 \# 3$ & $9 \# 6$ & - & $11 \# 1$ & $12 \# 6$ & $13 \# 5$ & $14 \# 4$ \\
\hline & & & & & & & & $11 \# 7$ & & & \\
\hline & Irrigation amount & 6 & - & 12 & 12 & 12 & - & 12 & 12 & 12 & 6 \\
\hline & $\left(\right.$ ton $\cdot$ time $\left.^{-1} \cdot 667 \mathrm{~m}^{-2}\right)$ & & & & & & & 12 & & & \\
\hline & Topdressing amount & - & - & 8 & 10 & 12 & - & 12 & 8 & 8 & 4 \\
\hline & $\left(\mathrm{kg} \cdot\right.$ time $\left.^{-1} \cdot 667 \mathrm{~m}^{-2}\right)$ & & & & & & & 8 & & & \\
\hline \multirow[t]{3}{*}{ D } & Weeks\#day & $3 \# 3$ & - & $7 \# 3$ & $8 \# 1$ & $9 \# 4$ & - & $11 \# 1$ & $12 \# 1$ & $13 \# 1$ & $14 \# 1$ \\
\hline & $\begin{array}{l}\text { Irrigation amount } \\
\left(\text { ton } \text { time }^{-1} \cdot 667 \mathrm{~m}^{-2}\right)\end{array}$ & 6 & - & 12 & 12 & 12 & - & 12 & 12 & 12 & 6 \\
\hline & $\begin{array}{l}\text { Topdressing amount } \\
\left(\mathrm{kg} \cdot \text { time }^{-1} \cdot 667 \mathrm{~m}^{-2}\right)\end{array}$ & - & - & 8 & 10 & 12 & - & 12 & 12 & 12 & 4 \\
\hline CK & \multicolumn{11}{|c|}{$\begin{array}{l}\text { According to the local traditional irrigation and fertilization method, two times in April for } 10 \mathrm{~kg} \cdot \text { time } \\
\mathrm{m}^{-2} \text {, three times in May for } 15 \mathrm{~kg} \cdot \mathrm{time}^{-1} \cdot 667 \mathrm{~m}^{-2} \text {, three times in June for } 20 \mathrm{~kg} \cdot \text { time } \\
\mathrm{l}^{-1} \cdot 667 \mathrm{~m}^{-2} \text {. The fertilizer } \\
\text { is about } 125 \mathrm{~kg} \cdot 667 \mathrm{~m}^{-2} \text { and the water is subject to the actual measurement. The actual irrigation water in this } \\
\text { experiment is } 124 \mathrm{~m}^{3} \cdot 667 \mathrm{~m}^{-2} \text {. }\end{array}$} \\
\hline
\end{tabular}




\section{Results}

Effects of Different Irrigation Amount on Plant Height, Stem Diameter and Leaf Number of Tomato in Different Periods

As shown in Fig. 1, after 20 days of planting, the plant height of treatment $\mathrm{B}$ and $\mathrm{C}$ was significantly higher than $\mathrm{CK}$, the stem diameter of treatment $\mathrm{C}$ was significantly larger than CK and there was no significant difference among other treatments. The number of leaves of treatment $\mathrm{A}$ and $\mathrm{C}$ was significantly larger than $\mathrm{CK}$ and there was no significant difference between other treatments and CK. After 40 days of planting, the plant height of each treatment was significantly higher than $\mathrm{CK}$ and the plant height of treatment $\mathrm{B}$ and $\mathrm{C}$ was significantly higher than that of treatment $\mathrm{A}$ and $\mathrm{D}$. There was no significant difference in stem diameter, leaf number and CK between each treatment. After 60 days of planting, the plant height of treatment $\mathrm{C}$ was significantly higher than $\mathrm{CK}$ and the plant height of treatment $\mathrm{A}$ was significantly lower than $\mathrm{CK}$ and there was no significant difference between treatment $\mathrm{B}, \mathrm{D}$ and the plant height of treatment $\mathrm{C}$ and $\mathrm{CK}$. The stem diameter of each treatment was greater than $\mathrm{CK}$ and the stem diameter of treatment $\mathrm{B}$ and $\mathrm{C}$ was significantly greater than $\mathrm{CK}$ and the number of leaves of each treatment was greater than $\mathrm{CK}$, but there was no significant difference. The results showed that different irrigation treatments had different effects on the growth of tomato in different periods and treatment B, C and D promoted the growth of tomato in different periods, among which treatment $\mathrm{C}$ had the best effect.

\section{Effects of Different Irrigation Amount on Dry and Fresh Weight of Tomato Plants}

It can be seen from Fig. 2 that the dry and fresh weight of roots and leaves of treatment A, B, C and D were significantly higher than CK. Among them, the fresh and dry weight of root of treatment A was the largest, with $55.32 \%$ and $65.45 \%$ higher than CK and that of leaves of treatment $\mathrm{C}$ is the largest, with $88.87 \%$ and $76.81 \%$ higher than CK. The fresh weight of stem of treatment A was significantly $22.08 \%$ and $7.92 \%$ higher than CK. There was no significant difference between the fresh weight of stem of treatment $\mathrm{B}, \mathrm{C}$ and $\mathrm{D}$ and CK. The results showed that treatment $\mathrm{A}$ and $\mathrm{C}$ could promote the dry and fresh weight of roots, stems and leaves of tomato plants, which was more conducive to the growth of tomato.

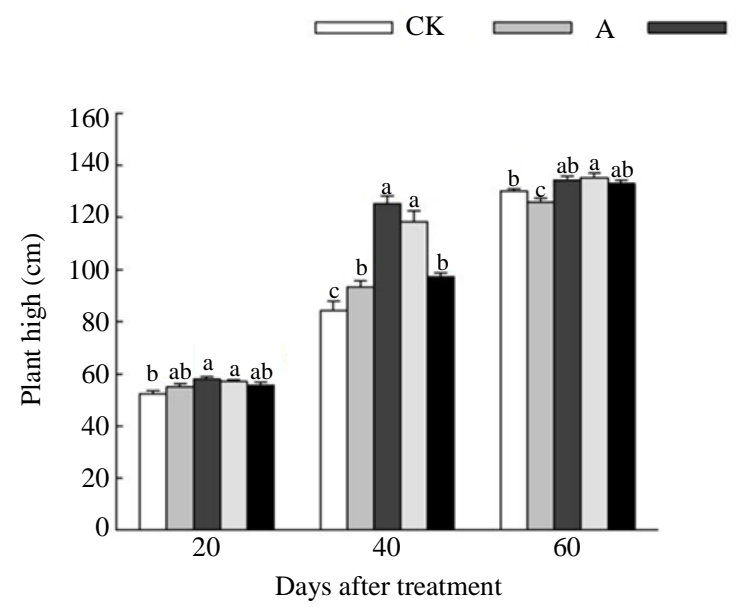

$\mathrm{B} \rightleftharpoons \mathrm{C} \rightleftharpoons \mathrm{D}$
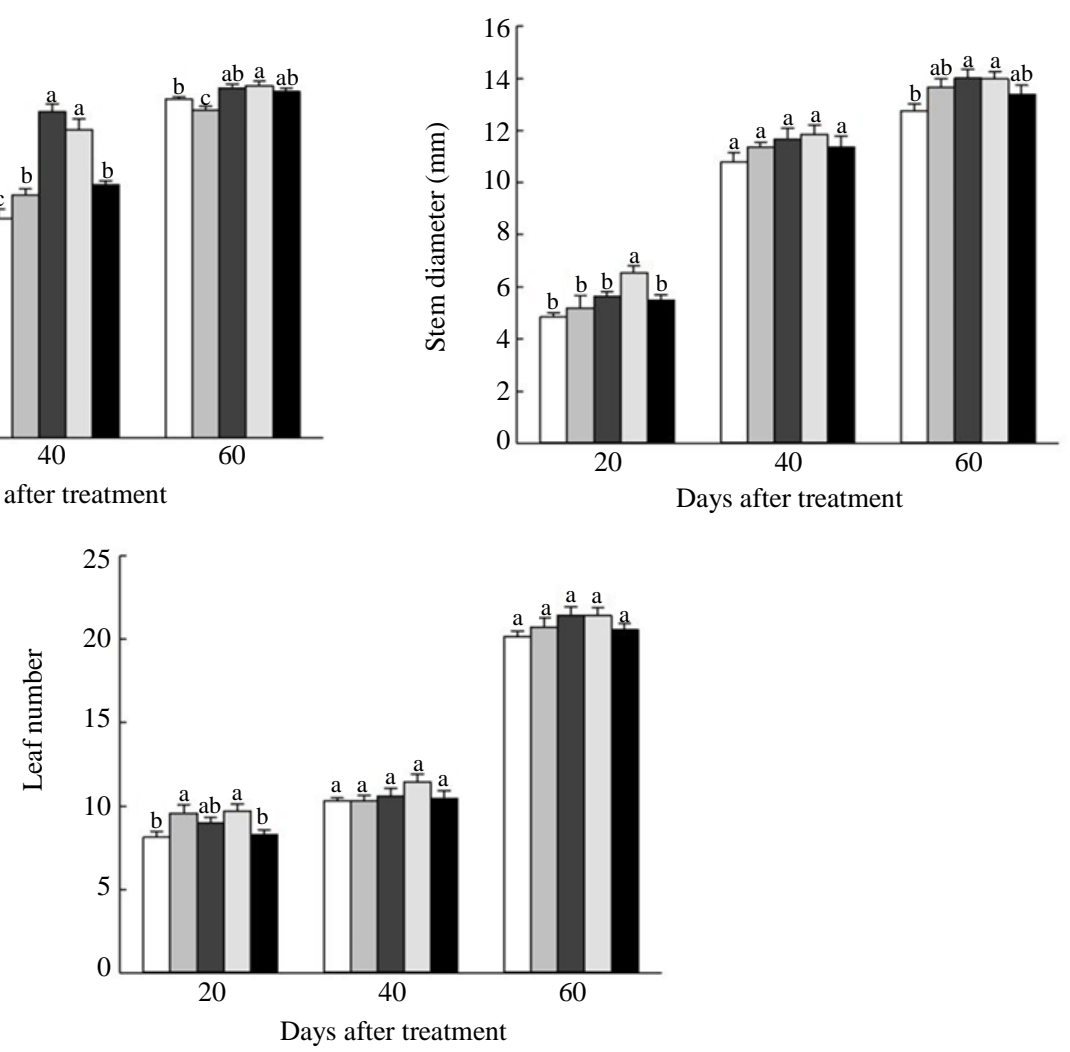

Fig. 1: Effects of different irrigation amount on plant height, stem diameter and leaf number of Tomato in different periods 


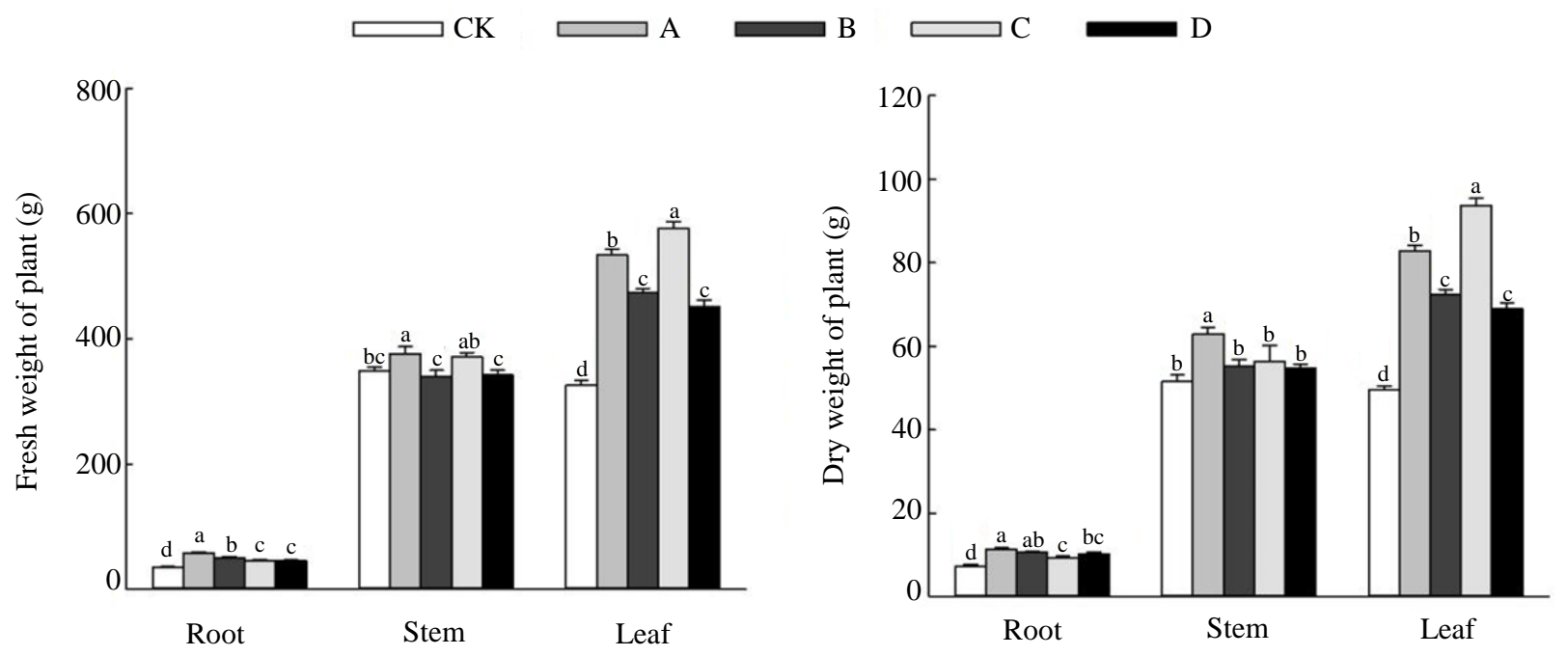

Fig. 2: Effects of different irrigation amount on dry and fresh weight of tomato plants

\section{Effects of Different Irrigation Amount on NPK Contents in Tomato Plants}

As shown in Fig. 3, the $\mathrm{N}$ content in the roots, stems and leaves of tomato treated with $\mathrm{C}$ was significantly higher than $\mathrm{CK}$ and that in the roots and leaves of tomato treated with A was significantly lower than CK. The $\mathrm{P}$ content in the roots, stems and leaves of tomato treated with $\mathrm{B}, \mathrm{C}$ and $\mathrm{D}$ was significantly higher than $\mathrm{CK}$ and $\mathrm{P}$ content in the roots and leaves of tomato treated with $\mathrm{C}$ was the highest, while that of tomato treated with $\mathrm{D}$ was the highest. The $\mathrm{K}$ content in roots, stems and leaves of tomato treated with $\mathrm{C}$ was higher than that of $\mathrm{CK}$ and there was no significant difference between the content of potassium in roots and leaves and that in stems. $\mathrm{K}$ content in roots and leaves of tomato treated with D was significantly lower than that of CK and the content of $\mathrm{K}$ in stems was significantly higher than that of $\mathrm{CK}$. The results showed that treatment $\mathrm{C}$ was propitious to the accumulation of $\mathrm{N}, \mathrm{P}$ and $\mathrm{K}$ in tomato plants and treatment $\mathrm{D}$ was propitious to the accumulation of $\mathrm{P}$ and $\mathrm{K}$ in roots, stems and leaves of tomato.

\section{Effects of Different Irrigation Amount on NPK Contents in Different Soil Layers}

From Fig. 4, except for the difference between the nitrogen content of treatment $\mathrm{D}$ and that of basicsoil samples in $20-40 \mathrm{~cm}$ soil layer, the $\mathrm{N}$ content of each soil layer of other treatments was significantly higher than that of basicsoil samples and the $\mathrm{N}$ content of each treatment in $0-20 \mathrm{~cm}$ soil layer was lower than that of
CK. The $\mathrm{N}$ content of treatment $\mathrm{D}$ in $20-40 \mathrm{~cm}$ soil layer was significantly lower than $\mathrm{CK}$, the $\mathrm{N}$ content of $\mathrm{A}, \mathrm{B}$ and $C$ in $20-40 \mathrm{~cm}$ soil layer was significantly higher than CK. The N content of each treatment in $40-60 \mathrm{~cm}$ soil layer was higher than $\mathrm{CK}$ and the differences between other treatments and CK except treatment B were significant. The $\mathrm{P}$ content of each treatment in 0-20 $\mathrm{cm}$ soil layer was lower than $\mathrm{CK}$ and higher than basicsoil samples. The $\mathrm{P}$ content of treatment $\mathrm{C}$ in 20-40 $\mathrm{cm}$ soil layer was significantly higher than $\mathrm{CK}$, the other treatments were significantly lower than $\mathrm{CK}$ and basicsoil samples. The $\mathrm{P}$ content of treatment $\mathrm{B}, \mathrm{C}$ and $\mathrm{D}$ in 40-60 cm soil layer was significantly lower than CK and basicsoil samples. The $\mathrm{K}$ content of $\mathrm{CK}$ and treatment A in $0-40 \mathrm{~cm}$ soil layer is significantly lower than that of basicsoil samples and the K content in 40$60 \mathrm{~cm}$ soil layer was lower than or equal to that of basicsoil samples. The K content of treatment B in $0-40 \mathrm{~cm}$ soil layer was significantly lower than CK and there was no significant difference between the $\mathrm{K}$ content in $40-60 \mathrm{~cm}$ soil layer and CK. There was no significant difference in $\mathrm{K}$ content between treatment $\mathrm{C}$ in $0-40 \mathrm{~cm}$ soil layer and CK. There was no significant difference between $\mathrm{K}$ content and CK in D 0-20 cm and 40-60 cm soil layers. K content in 20$40 \mathrm{~cm}$ soil layer was significantly higher than CK. The results showed that treatment $\mathrm{D}$ has a better effect on slowing down the accumulation of $\mathrm{N}$ and $\mathrm{P}$ in the soil and could also reduce the accumulation of $\mathrm{K}$ to a certain extent. Treatment $\mathrm{B}$ and $\mathrm{C}$ have a better effect on slowing down the accumulation of $\mathrm{K}$ in the soil; On the whole, the effect of treatment $\mathrm{D}$ on the enrichment of $\mathrm{N}, \mathrm{P}$ and $\mathrm{K}$ in improved soil is better. 

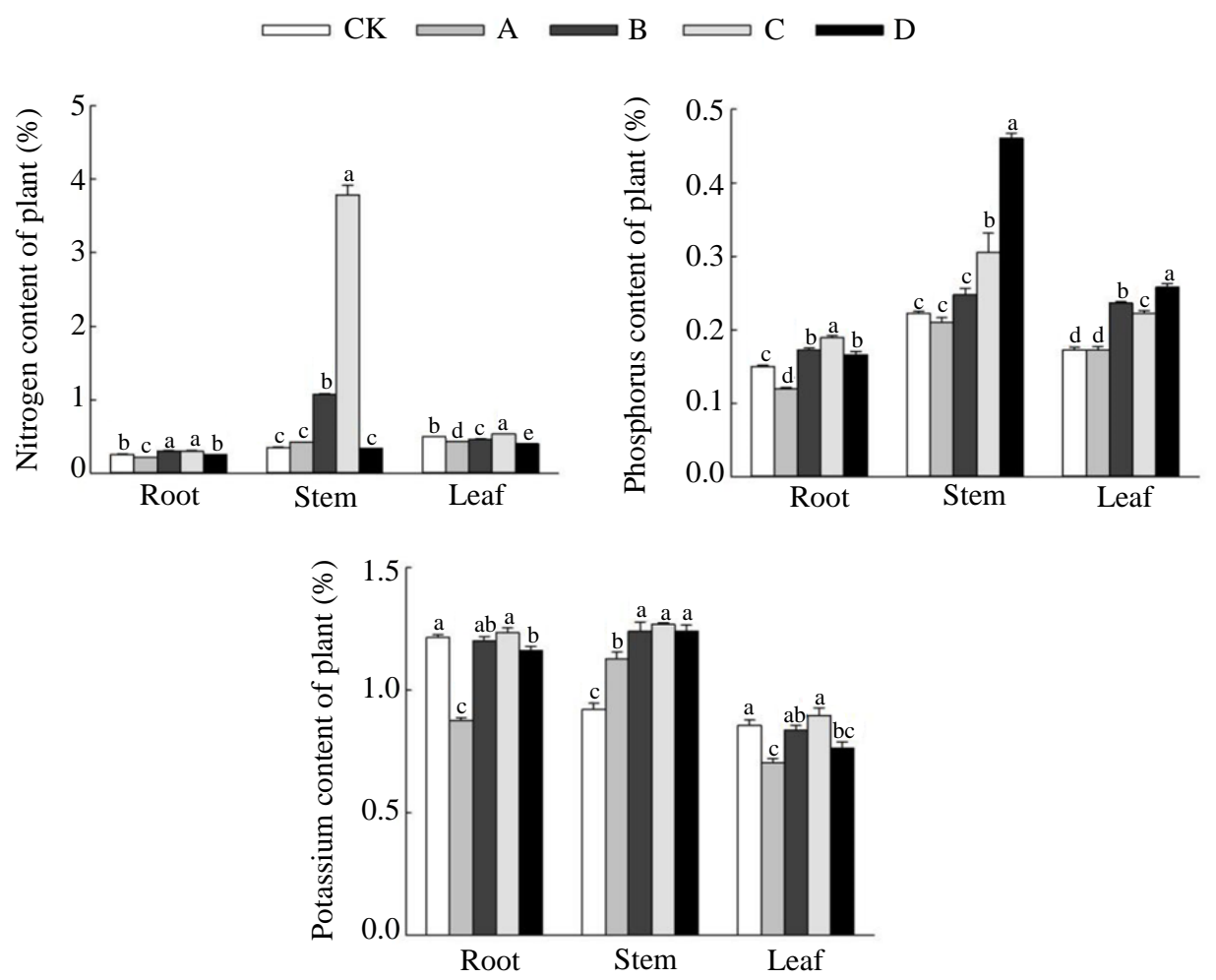

Fig. 3: Effects of different irrigation amount on N, P and K content of tomato plants
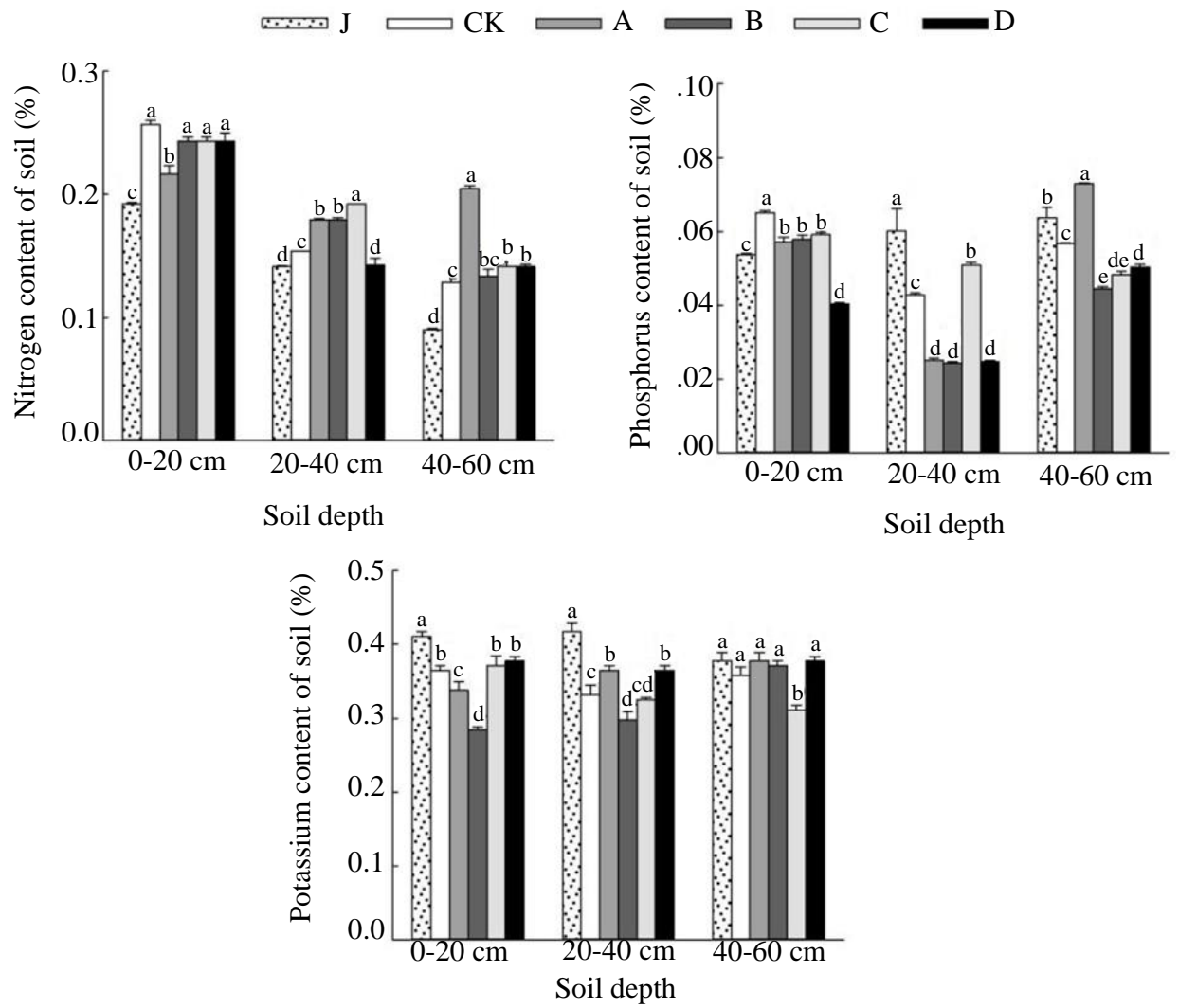

Fig. 4: Effects of different irrigation amount on N, P and K content of different soil layer. J: basicsoil samples 
Table 2: Effects of different irrigation amount on tomato quality

\begin{tabular}{llllllll}
\hline Treatments & $\begin{array}{l}\text { Soluble sugar } \\
\text { content }\left(\mathrm{g} \cdot 100 \mathrm{~g}^{-1}\right)\end{array}$ & $\begin{array}{l}\text { Organic acid } \\
\text { content }(\%)\end{array}$ & $\begin{array}{l}\text { Sugar-acid } \\
\text { ratio }\end{array}$ & $\begin{array}{l}\text { Lycopene } \\
\left(\mathrm{mg} \cdot \mathrm{L}^{-1}\right)\end{array}$ & $\begin{array}{l}\text { Soluble protein } \\
\left(\mathrm{mg} \cdot \mathrm{g}^{-1)}\right.\end{array}$ & $\begin{array}{l}\text { Soluble } \\
\text { soild }(\%)\end{array}$ & $\begin{array}{l}\text { VC content } \\
(\mathrm{mg} \cdot 100 \mathrm{~g}\end{array}$ \\
\hline CK & $0.410 \pm 0.0012 \mathrm{a}$ & $6.22 \pm 0.19 \mathrm{~b}$ & $6.62 \pm 0.21 \mathrm{c}$ & $0.15 \pm 0.01 \mathrm{e}$ & $2.00 \pm 0.03 \mathrm{~d}$ & $0.51 \pm 0.03 \mathrm{a}$ & $8.33 \pm 0.25 \mathrm{c}$ \\
A & $0.405 \pm 0.001 \mathrm{a}$ & $5.36 \pm 0.25 \mathrm{c}$ & $7.67 \pm 0.37 \mathrm{~b}$ & $0.17 \pm 0.01 \mathrm{~d}$ & $2.41 \pm 0.03 \mathrm{~b}$ & $0.56 \pm 0.02 \mathrm{a}$ & $10.64 \pm 0.16 \mathrm{~b}$ \\
$\mathrm{~B}$ & $0.396 \pm 0.002 \mathrm{~b}$ & $5.17 \pm 0.19 \mathrm{c}$ & $7.72 \pm 0.28 \mathrm{~b}$ & $0.56 \pm 0.02 \mathrm{a}$ & $2.16 \pm 0.02 \mathrm{c}$ & $0.52 \pm 0.01 \mathrm{a}$ & $10.11 \pm 0.19 \mathrm{~b}$ \\
$\mathrm{C}$ & $0.406 \pm 0.001 \mathrm{a}$ & $7.08 \pm 0.32 \mathrm{a}$ & $5.81 \pm 0.28 \mathrm{c}$ & $0.39 \pm 0.02 \mathrm{~b}$ & $1.10 \pm 0.02 \mathrm{e}$ & $0.53 \pm 0.02 \mathrm{a}$ & $3.91 \pm 0.23 \mathrm{~d}$ \\
$\mathrm{D}$ & $0.399 \pm 0.003 \mathrm{~b}$ & $4.40 \pm 0.14 \mathrm{~d}$ & $9.11 \pm 0.29 \mathrm{a}$ & $0.19 \pm 0.01 \mathrm{c}$ & $2.64 \pm 0.04 \mathrm{a}$ & $0.57 \pm 0.03 \mathrm{a}$ & $12.59 \pm 0.19 \mathrm{a}$ \\
\hline
\end{tabular}

Table 3: Effects of different irrigation amount on tomato yield and water use efficiency

\begin{tabular}{llll}
\hline Treatments & Yield per plant $(\mathrm{kg})$ & Plot yield $(\mathrm{kg})$ & Water use efficiency $\left(\mathrm{kg} \cdot \mathrm{m}^{-3}\right)$ \\
\hline CK & $3.22 \pm 0.05 \mathrm{a}$ & $91.01 \pm 1.88 \mathrm{a}$ & $38.86 \pm 0.80 \mathrm{c}$ \\
A & $3.05 \pm 0.07 \mathrm{~b}$ & $90.68 \pm 1.62 \mathrm{a}$ & $39.58 \pm 0.0 .70 \mathrm{bc}$ \\
B & $3.00 \pm 0.06 \mathrm{~b}$ & $80.34 \pm 0.53 \mathrm{~b}$ & $39.44 \pm 0.25 \mathrm{bc}$ \\
C & $2.99 \pm 0.03 \mathrm{~b}$ & $81.60 \pm 0.30 \mathrm{~b}$ & $41.09 \pm 0.15 \mathrm{~b}$ \\
D & $3.32 \pm 0.05 \mathrm{a}$ & $93.77 \pm 0.93 \mathrm{a}$ & $51.17 \pm 0.51 \mathrm{a}$ \\
\hline
\end{tabular}

\section{Effects of Different Irrigation Amount on Tomato Quality}

As shown in Table 2, the soluble sugar content of treatment B and D was significantly lower than CK, the organic acid content of treatment $\mathrm{C}$ was significantly higher than $\mathrm{CK}$ and that of other treatments was significantly lower than CK. The sugar acid ratio and VC content of treatment $\mathrm{A}, \mathrm{B}$ and $\mathrm{D}$ were significantly higher than $\mathrm{CK}$ and the effect of treatment $\mathrm{D}$ was the best, with $37.61 \%$ and $51.14 \%$ higher than CK respectively. The content of lycopene in treatment A, B, $\mathrm{C}$ and $\mathrm{D}$ was significantly higher than $\mathrm{CK}$ and the content of treatment $\mathrm{B}$ was the highest. The soluble protein content of treatment $\mathrm{A}, \mathrm{B}$ and $\mathrm{D}$ was significantly higher than $\mathrm{CK}$ and the content of treatment $\mathrm{D}$ was the highest, with 32\% higher than CK. There was no significant difference between the content of soluble solids and CK and the content of treatment $\mathrm{D}$ was the highest, $11.76 \%$ higher than CK. The results showed that treatment $\mathrm{C}$ was the best for the accumulation of organic acids in tomato fruit and treatment $\mathrm{B}$ was the best for the accumulation of lycopene in tomato fruit. Treatment $\mathrm{D}$ was the best way to increase the content of soluble protein, soluble solids and VC in tomato fruit and increase the sugar acid ratio of tomato fruit and the yield of tomato per plant. Taken together, treatment $\mathrm{D}$ was best to fruit quality of tomato.

\section{Effects of Different Irrigation Amount on Tomato Yield and Water Use Efficiency}

It could be seen from Table 3 that there was no significant difference between treatment D and CK and other treatments were significantly lower than CK. There was no significant difference between CK and the yield of tomato plot treated with $\mathrm{A}$ and $\mathrm{D}$, but treatment $\mathrm{B}$ and $\mathrm{C}$ are significantly lower than $\mathrm{CK}$. The water use efficiency of treatment C and D was significantly higher than $\mathrm{CK}$ and there was no significant difference between $\mathrm{CK}$ and treatment $\mathrm{A}$ and $\mathrm{B}$. Considering comprehensively, the effect of treatment D was the best, which can promote water use efficiency, save water resources and increase the yield of tomato.

\section{Discussion}

Water saving irrigation is an important measure to alleviate the shortage of water resources in China. In this study, the water use efficiency of tomato was higher than that of traditional flooding irrigation by using microporous membrane water-fertilizer integrated technology and the highest water use efficiency was increased by $30.65 \%$ and water saving rate is $31.68 \%$ when the irrigation amount is $84 \mathrm{~m}^{3} .667 \mathrm{~m}^{-2}$. Previous studies have shown that drip irrigation generally saved 30-50\% water than flood irrigation (Fan et al., 2011; Nasiraei et al., 2018). It could be seen that the watersaving efficiency of microporous membrane irrigation technology was the same as that of drip irrigation technology. Xue et al. (2013) found that the water use efficiency of Tomato under drip irrigation could reach $53.33 \mathrm{~kg} \cdot \mathrm{m}^{-3}$, which was the same as the results of this study. However, Liu and Liu (2005) found that the water use efficiency of tomato under drip irrigation was 3.8 times higher than that under flood irrigation, which may be caused by the different irrigation amount of flood irrigation. In addition, Fan et al. (2015) showed that the input of drip irrigation equipment was 27000 yuan $\mathrm{hm}^{-2}$ and the service life was 5 years. In this study, the waste shed film without damage wa used, which was lower than the input of drip irrigation system. The microporous membrane irrigation technology used in this study could be used as an effective water-saving irrigation technology in production.

Water plays an important role in plant morphogenesis and more. Appropriate soil water was conducive to promoting plant growth (Geisseler et al., 2020; Olson and Pittermann, 2019; Ye et al., 2020). In this study, the stem diameter and fresh and dry weight of plants under 
different irrigation treatments are increased. In addition, Microporous membrane irrigation was beneficial to the accumulation of $\mathrm{N}, \mathrm{P}$ and $\mathrm{K}$ in tomato plants in this research. Previous studies have found that the accumulation of nutrient elements in plants was often positively correlated with the growth of plants (Cui et al., 2020; Jiang et al., 2019). This indicated that the treatment of microporous membrane irrigation could improve the soil moisture content, increase the nutrient absorption of tomato plants and then promote the growth of tomato. The results of Xing et al. (2014) also proved that suitable soil water was conducive to the absorption of nutrients by plants and the effect of promoting fertilizer by water. In this study, when the amount of irrigation is $96 \mathrm{~m}^{3} \cdot 667$ $\mathrm{m}^{-2}$, the growth of tomato was the best and the NPK accumulation of plants was the most.

In addition to fertilization factors, the nutrient element content in the cultivated soil was affected by plants and irrigation. On the one hand, plants would absorb a large number of nutrient elements in the growth process and on the other hand, the nutrient elements in the surface soil would migrate downward with water (Frensch et al., 1996; Jarvis, 2007). In this study, the P content of treatment D in $0-20 \mathrm{~cm}$ and $20-$ $40 \mathrm{~cm}$ soil was significantly lower than that of $\mathrm{CK}$, equal to or less than that of basic soil, while the $\mathrm{P}$ content of plant was the highest and the $\mathrm{P}$ content of 40-60 cm soil was lower. Therefore, when the irrigation amount was $84 \mathrm{~m}^{3} \cdot 667 \mathrm{~m}^{-2}$, the applied phosphorus elements are completely absorbed by plants and the phosphorus concentration was less. Except for treatment Din 20-40 cm, the nitrogen content in the soil was higher than that in the base soil in $0-20 \mathrm{~cm}, 20-40$ $\mathrm{cm}$ and 40-60 $\mathrm{cm}$ of each treatment, which may be caused by the large amount of nitrogen application and the leaching of nitrogen caused by irrigation. But for the $\mathrm{K}$ content in soil, the $\mathrm{K}$ content of each treatment in $0-20 \mathrm{~cm}$ and $20-40 \mathrm{~cm}$ was significantly lower than that of the base soil and there was no significant difference between the $\mathrm{K}$ content of each treatment in 40-60 cm and that of the base soil except for treatment $\mathrm{C}$. It showed that the application amount of potassium fertilizer in this study may be low, which did not lead to the deep transfer of potassium to the soil.

WUE is an important water use indicators in the study of sustainable irrigated agriculture (Ucar et al., 2019). Qu et al. (2019) have found improved WUE may be achieved by reducing the water supply. In this study, after adopting the technique of microporous membrane water-fertilizer integration for non-pressure gravity irrigation, we found that the WUE of tomato was significantly higher than that under the traditional fertilizing rate and that, with the lowering of fertilizing rate, the overall WUE presented an increasing trend, the highest WUE occurred under the lowest watering rate, where per plant and plot yields were significantly higher than $\mathrm{CK}$ and the quality of fruit was best. A irrigation amount of $96 \mathrm{~m}^{3} \cdot 667 \mathrm{~m}^{-2}$ resulted in suitable growth, which was lower than that under a fertilizing rate of $84 \mathrm{~m}^{3} \cdot 667$ $\mathrm{m}^{-2}$. This finding was probably due to the irrigation amount of $96 \mathrm{~m}^{3} \cdot 667 \mathrm{~m}^{-2}$ resulting in over nutrition and overgrowth of plants, thereby impacting their reproduction and growth in the late stage. However, excessive reduction of irrigation reduced the crop yields (Li et al., 2017).

\section{Conclusion}

In conclusion, under the condition of the microporous membrane water-fertilizer integrated technology, the optimal irrigation water volume was $84 \mathrm{~m}^{3} .667 \mathrm{~m}^{-2}$. Under this irrigation amount, the water saving was $30.65 \%$, the water use efficiency was increased by $31.68 \%$. The yield per plant was increased by $3.11 \%$ and the fruit quality was the best. This experiment used the form of fixed amount of fertilizer and water to study the effect of different irrigation amount on tomato fruit, yield, growth and the change of nitrogen, phosphorus and potassium content in plants and soil. Our results preliminarily identified a irrigation amount comparable to traditional irrigation and irrigation practice which could improve fruit quality of tomato and WUE, but also ameliorate the problem of the abundant enrichment of nutrient elements in soil, which provided reference for irrigation of tomato in spring in Plastic Greenhouse. In future, we will continue to adjust the lower limit of irrigation amount and study the mechanism of the effect of irrigation water on the yield and quality of tomato, so as to provide scientific basis for the production irrigation water quota.

\section{Acknowledgement}

The work is supported by the Special support project for the construction of technology system of Bulk vegetable industry in Henan Province (S2015-03).

\section{Author's Contributions}

Xiao Huaijuan: Research concept and design.

Du Qingjie: Data analysis and interpretation.

Zhang Jiaxin: Critical revision of the article.

Li Juanqi: Final approval of article.

Wang Jiqing: Writing the article.

\section{Ethics}

This article is original and contains unpublished material. The corresponding author confirms that all of the other authors have read and approved the manuscript and no ethical issues involved. 


\section{References}

Al-Ghobari, H.M. and A.Z. Dewidar, 2018. Integrating deficit irrigation into surface and subsurface drip irrigation as a strategy to save water in arid regions. Agric. Water Manage., 209: 55-61.

DOI: 10.1016/j.agwat.2018.07.010

Ayars, J.E., C.J. Phene and R.B. Hutmacher, 1999. Subsurface drip irrigation of row crops: A review of 15 years of research at the water management research laboratory. Agric. Water Manage., 42: 1-27. DOI: 10.1016/S0378-3774(99)00025-6

Bremner, J.M., 1960. Determination of nitrogen in soil by the Kjeldahl method. J. Agric. Sci., 55: 11-33. DOI: $10.1017 / \mathrm{S} 0021859600021572$

Burcea, M., D. Cretu and M. Musat, 2016. Study regarding the influence of NPK fertilizers on the total nitrogen content from tomato (Lycopersicum esculentum). Romanian Biotechnol. Lett., 21: 11144-11148.

Cui, J.T., G.C. Shao and J. Lu, 2020. Yield, quality and drought sensitivity of tomato to water deficit during different growth stages. Sci. Agricola.

Fan, Z.B., M.J. Liu and X.M. Zhang, 2011. Effect of dripper fertigation on tomato yield and apparent $\mathrm{N}$ balance in a greenhouse. Plant Nutrit. Fertilizer Sci., 17: 970-976.

Fan, Z.B., S. Lin and Q. Chen, 2015. Effect of drip fertigation on water and nitrogen use efficiency and nitrate residues in a greenhouse. J. China Agric. Univ., 20: 135-143.

Frensch, J., T.C. Hsiao and E. Steudle, 1996. Water and solute transport along developing maize roots. Planta, 198: 348-355.

DOI: $10.1007 / \mathrm{BF} 00620050$

Geisseler, D., B.J. Aegerter and E.M. Miyao, 2020. Nitrogen in soil and subsurface drip-irrigated processing tomato plants (Solanum lycopersicum L.) as affected by fertilization level. Sci. Horticul.

Hanson, B.R. and D.M. May, 2006. Crop coeffiffifficients for drip-irrigated processing tomato. Agric. Water Manage., 81: 381-399.

DOI: $10.1016 /$ j.agwat.2005.04.007

Jarvis, N.J., 2007. A review of non-equilibrium water flow and solute transport in soil macropores: Principles, controlling factors and consequences for water quality. Eur. J. Soil Sci., 58: 523-546. DOI: 10.1111/j.1365-2389.2007.00915.x

Jiang, X.L., Y.L. Zhao and L. Tong, 2019. Quantitative analysis of tomato yield and comprehensive fruit quality in response to deficit irrigation at different growth stages. Hortscience, 54: 1409-1417. DOI: 10.21273/HORTSCI14180-19
Karlberg, L. and F.W.P. Vries, 2004. Exploring potentials and constraints of low-cost drip irrigation with saline water in sub-Saharan Africa. Phys. Chem. Earth, 29: 1035-1042.

DOI: $10.1016 /$ j.pce.2004.08.004

Li, H.S., Q. Sun and S.J. Zhao, 2000. The experiment principle and technique on plant physiology and biochemistry. Higher Educ. Press, Beijing.

Li, J.M., X.Y. Fan and F.F. Yan, 2017. Effect of different irrigation amount based on transpiration model on yield and quality of muskmelon. Trans. Chinese Society Agric. Eng., 33: 156-162.

Li, N., Y.H. Kang and X.B. Li, 2019. Lateral flushing with fresh water reduced emitter clogging in drip irrigation with treated effluent. Irrigat. Sci., 37: 1-9. DOI: $10.1007 / \mathrm{s} 00271-019-00637-3$

Liu, M.C. and X.L. Liu, 2005. Effect of different irrigation methods on plant growth and yield of tomato. Acta Agric. Boreali-Sinica.

Mostafa, H.M.S., R. El-Nady and M. Awad, 2018. Drip irrigation management for wheat under clay soil in arid conditions. Ecol. Eng., 121: 35-43.

DOI: 10.1016/j.ecoleng.2017.09.003

Nasiraei, J.R., H. Ansari and K. Esmaeili, 2018. Effect of irrigation timing on the eggplant performance under drip irrigation. Crop Res., 53: 81-87. DOI: $10.5958 / 2454-1761.2018 .00013 . X$

NBS, 2018. China statistical yearbook. China statistical press, Beijing.

Olson, M.E. and J. Pittermann, 2019. Cheap and attractive: Water relations and floral adaptation. New Phytologist, 223: 8-10. DOI: 10.1111/nph.15839

Qu, F., J.J. Jiang and J.W. Xu, 2019. Drip irrigation and fertilization improve yield, uptake of nitrogen and water-nitrogen use efficiency in cucumbers grown in substrate bags. Plant Soil Environ., 66: 328-335.

Singh, M., R.K. Saini and S. Singh, 2019. Potential of integrating biochar and deficit irrigation strategies for sustaining vegetable production in water-limited regions: A review. Hortscience, 54: 1872-1878. DOI: $10.21273 /$ HORTSCI14271-19

Song, M.Z., W. Feng and W. Ji, 2009. Evaluation method of soil water distribution uniformity under conditions of Fifield subsurface drip irrigation. Trans. Chinese Society Agric. Eng., 25: 51-57.

Ucar, Y., S. Kazaz, F. Eraslan and H. Baydar, 2019. Effects of different irrigation water and nitrogen levels on the water use, rose flower yield and oil yield of Rosa damascene. Agric. Water Manage., 182: 94-102.

Wang, J.Q., Y.P. Zhao and J.T. Shi, 2020a. An uniform and quantitative irrigation equipment: China, ZL $201710751922 . X$. 
Wang, J.W., Y. Li and W.Q. Niu, 2020b. Investigating the proper application rate of nitrogen under mulched drip irrigation to improve the yield and quality of tomato in saline soil. Agronomy, 293: 1-14. DOI: 10.3390 /agronomy 10020293

Xing, Y.Y., F.C. Zhang and Y. Zhang, 2014. Irrigation and fertilization coupling of drip irrigation under plastic film promotes tomato's uptake and growth. Trans. Chinese Society Agric. Eng., 30: 70-80.
Xue, W.L., W.Q. Zhu and Z.Z. Zhang, 2013. Effects of the tomato growth and water use efficiency in sunlight greenhouse by moistube-irrigation. Agric. Res. Arid Areas, 31: 61-66.

Ye, X.H., H.D. Liu and X.H. Zhang, 2020. Impacts of irrigation methods on greenhouse gas emissions/absorptions from vegetable soils. J. Soils Sediments, 20: 723-733.

DOI: $10.1007 / \mathrm{s} 11368-019-02422-3$ 